\title{
Alcohol 類兔皮内注射による局所毛細血管透過性克進
}

\author{
鈴木守, 豊 島 泰 光 \\ (ポーラ化成工業株式会社研究所〔所長 : 藤原万亀雄】) \\ （昭和44年 9 月 29 日受付）
}

Propylene glycol p Polyoxyethylene glycol のごとき Alcohol は薬理学的に毒性の少ない稀釈剤として

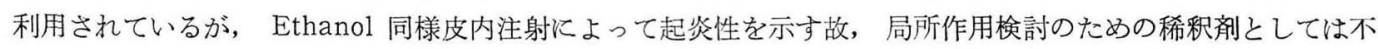
適当であることを示した ${ }^{1)}$. 従って, Alcohol 類の起炎性ないしは局所作用汪興味を抱き，すでに，一連の一価 Alcohol の化学構造とそれら皮内注入による局所毛細血管透過性光進との関係について報告した ${ }^{2)}$ が, 引続き, 以下の点について検討したので, それら成積について報告し, さらに, 先報の結果22 と併せて, Alcohol 類鬼皮 内注入による毛細血管透過性元進機序に関して考察を加兄る.

1）多価 Alcohol 鬼皮内注入による毛細血管透過性圥進とそれら化学構造との関係

2) Alcohol 類束皮内注入による毛細血管透過性立進に怙よぼす抗炏症薬の影響

3) Alcohol 類の二, 三の物理化学的性質

\section{実験材料および実験方法}

体重 $2 \mathrm{~kg}$ 前後の雑系白鬼を無麻酔にて腹位に固定し, 背部を広範囲に除毛した。 $40 \mathrm{mg} / \mathrm{kg}$ Evans blue を静注し，水あるいは Isopropyl myristate (以下 IPM) に溶解した検液 $0.1 \mathrm{ml}$ を皮内注射した。皮内注射 $1^{\text {h }}$ 後に放血致死せしめ, 直ちに, 背部皮覤を剥離した。皮内注入中心部にしばしば認められる Non-blued area (以下 $\mathrm{NA}$ ) $\mathrm{mm}^{2}$ 単位で測定した後, 漏出色素量 (以下 $\mathrm{E} 610$ ) を波長 $610 \mathrm{~m} \mu$ 亿て分光光度計的に定量 し32, 毛紐血管透過性光進の指標とした. 特記しない限り, この方法によって以下の実験を行なった。

\section{1）毛細血管透過性亢進と化学構造}

1-1）二価 Alcohol の炭素数との関係

炭素鎖の雨末端に水酸基を有する Ethanediol, Propanediol-1.3, Butanediol-1.4, Pentanediol-1.5 敊よび Hexanediol-1.6 の50括よび25\%溶液を検液として皮内注射した。

1-2） 水酸基の数との関係

炭素数 2〜6のそれぞれについて, 水酸基数の異なるAlcohol を皮内注入した. すなわち, 使用したAlcohol は $\mathrm{C}_{2}$ では Ethanol と Ethanediol, $\mathrm{C}_{3}$ では Propanol-1 と Propanediol-1-3, $\mathrm{C}_{4}$ では Butanol-1, Butanediol-1.4 と Butanetriol-1.2.4, $\mathrm{C}_{5}$ では Pentanol-1 と Pentanediol-1.5 扤よび $\mathrm{C}_{6}$ では Hexanol-1, Hexanediol-1.6, Hexanetriol-1.2.6 と Sorbitol であった.

1-3） 買性体間の作用の比較

Propanediol の異性体 -1.3 と -1.2 , Butanediolの異性体 $-1.4-1.3$ そ -2.3 乱よび Hexanediol の 異性体 -1.6 と -2.5 を検体とした.

1-4） Polyoxyethylene glycol の分子量との関係

Polyoxyethylene glycol の No. 200, No. 300, No. 400, No. 600, No. 1000 , No. 1540 , No. 4000, No. 6000 の50および30\%ならびに $0.5 \mathrm{M}$ 水溶液を皮内注射し, それら分子量と毛細血管透過性え進との関倸を検討 した.

\section{2) 抗 Histamine 薬の影響}

生理的食塩水を静注したものを対照として，30 mg/kg Diphenhydramine (Histamine 皮内注射飞よる毛 
細血管透過性立進を阻害する用量 ${ }^{4)}$ ) 静脈内に前処置した秉に, 静注 1,2 および $3^{\text {h }}$ 後に Ethanol, Butanol1, Hexanol-1, Octanol-1 および Decanol-1 の50\%溶液（稀釈剤 IPM）を皮内注射した。

さらに, 遊離 Histamine ${ }^{5)}$ 打よび皮内注射した Histamine ${ }^{6)}$ の作用は速效的かつ一過性である故, 皮内注 入直後拉よび $1^{\mathrm{h}}$ 以降に生ずる毛細血管透過性充進を抗 Histamine 薬が抑制するか否かを検した。対照群には 生理的食塩水を，他群には $30 \mathrm{mg} / \mathrm{kg}$ Diphenhydramine 静注し，その $1^{\mathrm{h}}$ 後に検液を皮内注射した. Evans blue 静注は皮内注射直前と $1^{\mathrm{h}}$ 後に行ない, Evans blue 静注 $1^{\mathrm{h}}$ 後に動物を殺した。検液には IPM に25\% に溶解した Ethanol, Propanol-1 と Butanol-1 および 0.01\% Histamine 水溶液を用いた.

\section{3) 抗炎症薬の影響}

予じめ, Sodium salicylate と Dipotassium glycyrrhitinate の各 $500 \mathrm{mg} / \mathrm{kg}$ を腹腔内に, $10 \mathrm{mg} / \mathrm{kg}$ Cortisone acetate 筋肉内に注射し，対照群には生理的食塩水を腹腔内投与した。その $2^{\mathrm{h}}$ 後に, Ethanol, Butanol-1, Hexanol-1, Octanol-1 おょび Decanol-1 の50拈よび25\%溶液（稀釈剤 IPM）を皮内注射した.

\section{4）Alcohol の油/水分配率}

炭素数 1 ～12の $n$-Alcohol を IPM 中に25\%に溶解し, IPM と同用量の水を加光た，この混合液を分液沪 斗中に移し，振盜機にて $5^{\mathrm{m}}$ 間振盜した。振盪によって, これら混液は乳濁したので，分離までの時間を観察 乙, 一晚放置した後, 水層と IPM 層を分取し, これら両層に含まれる Alcohol 量を Gas chromatography にて定量した.

\section{実 験 成 績}

\section{1）化学構造と毛細血管透過性元進}

\section{1-1）炭素数との関係}

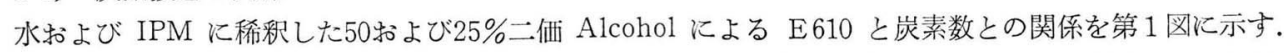

50 おび25\%の Alcohol の水扮よび IPM 溶液はいずれも炭素数の増加に伴って, ほぼ直線的に E 610 の 增加を来した。 これら直線の勾配は $50 \%$ 水溶液で最も急峻であり，逆に，緩やかな勾配を示したものは $50 \%$

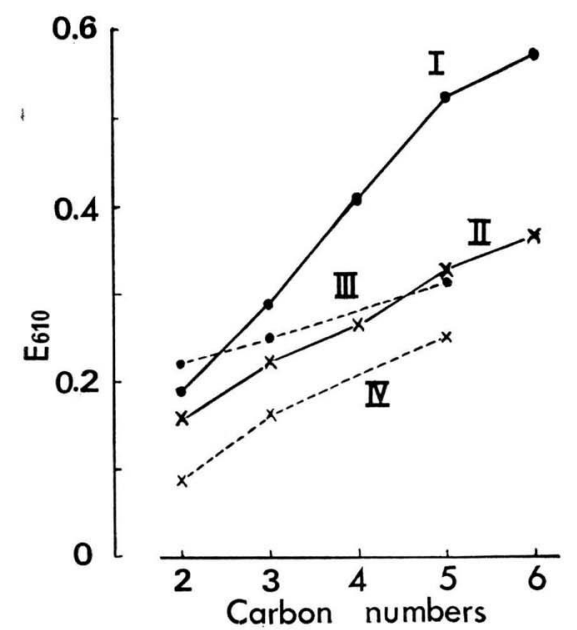

第1図二価 Alcohol 皮内注入による $\mathrm{E} 610$ と炭素 数との関係
I. $50 \%$ 水溶液
II. $25 \%$ 水溶液
III. $50 \%$ IPM 溶液;
IV. $25 \%$ IPM 溶液

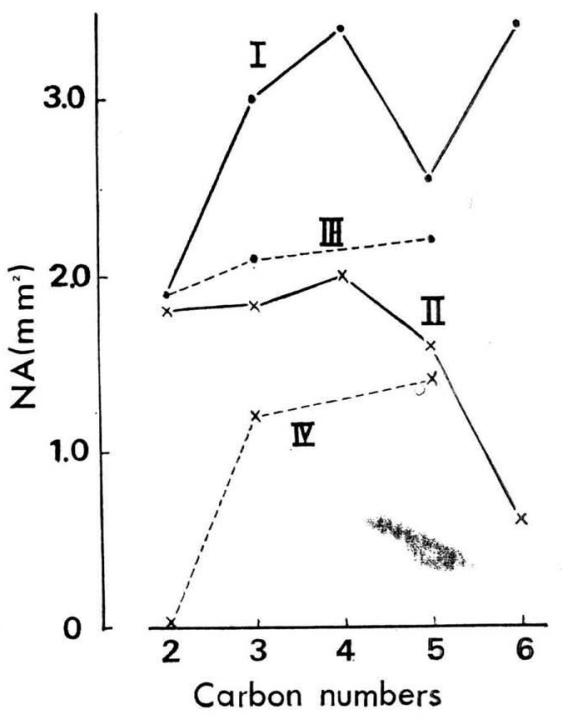

第 2 図 二価 Alcohol 皮内注入による NA と炭素数 との関係
I. $50 \%$ 水溶液 ； II. $25 \%$ 水溶液
III. 50\% IPM 溶液； IV. $25 \%$ IPM 溶液 
IPM 溶液であった。すなわち，50\%溶液の場合，低級の Ethanedio1 や Propanedio1 では稀釈剂の相違による E610 の差はわずかであったが，Pentanediol では IPM 溶液による E610よりも水溶液によるものにおいて 有意的に強度であった。また，50\% Pentanediol の IPM 溶液による E610 は 25\% Pentanediol 水溶液のそ れと同程度であった。 $25 \%$ 二価 Alcohol では IPM 溶液よりも水溶液にて大なる E610を示し, これら炭素数

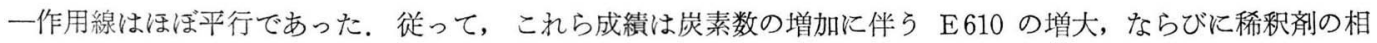
違に基ずく作用強度の変動を示した。

次に，第 2 図に二価 Alcohol によるNA と炭素数との関係を示す. 水溶液の場合，50\%と25\%のものとの 間に著しく相違した炭素数一作用線が得られた。すなわち，50\%の場合， C $C_{5}$ を除くと直線的ではないが炭素数 の増加とともに NA が大となったのに対し， $25 \%$ の場合， $\mathrm{C}_{2}$ 〜 $\mathrm{C}_{4}$ 間の $\mathrm{NA}$ に著差はなかったが $\mathrm{C}_{4}$ 以上の二 価 Alcohol による NA は炭素数の増加に伴って小となった。 その結果として, Ethanedio1 によるNA は25 と50\%との間汇差を示さなかったが, Hexanediol では50\%のものが25\%のものの約 6 倍を示した.

IPM を稀釈剤とするとき，二価 Alcohol による NA はわずかではあるが炭素数の増加によって大となっ た. 25\% Ethanediol は NA を作らなかった。一般に, IPM そ稀糔した二価 Alcohol による NA は E610 と同様, 水溶液によるものより小であった。

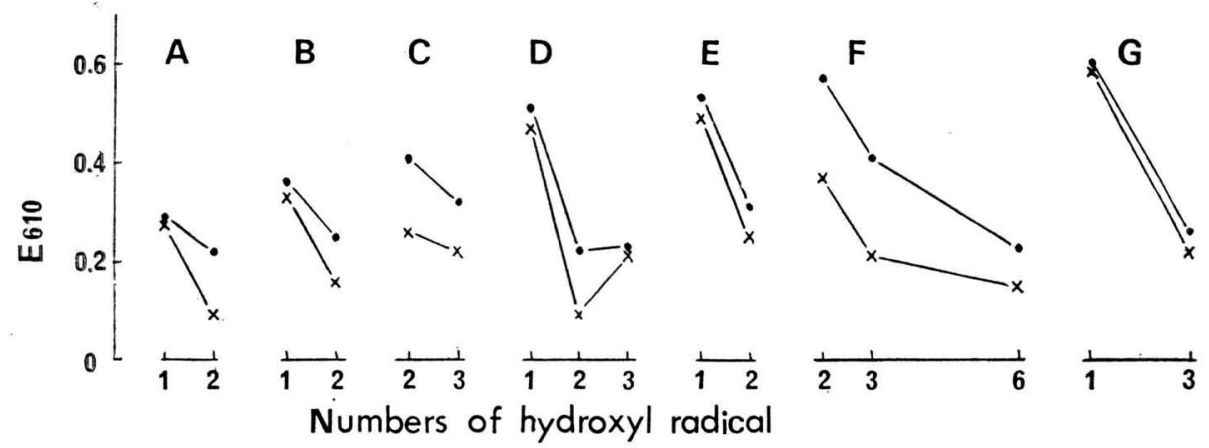

第 3 図 E610 に拉よぼす水酸基の数の影響

A. $\mathrm{C}_{2}$ alcohol の IPM 溶液. B. $\mathrm{C}_{3}$ alcohol の IPM 溶液. C. $\mathrm{C}_{4}$ alcohol の水溶液.

D. $\mathrm{C}_{4}$ alcohol の IPM 溶液. E. $\mathrm{C}_{5}$ alcohol の IPM 溶液. F. $\mathrm{C}_{6}$ alcohol の水溶液.

G. $\mathrm{C}_{6}$ alcohol の IPM 溶液. $\quad-150 \%$ 溶液. $\times-25 \%$ 溶液.

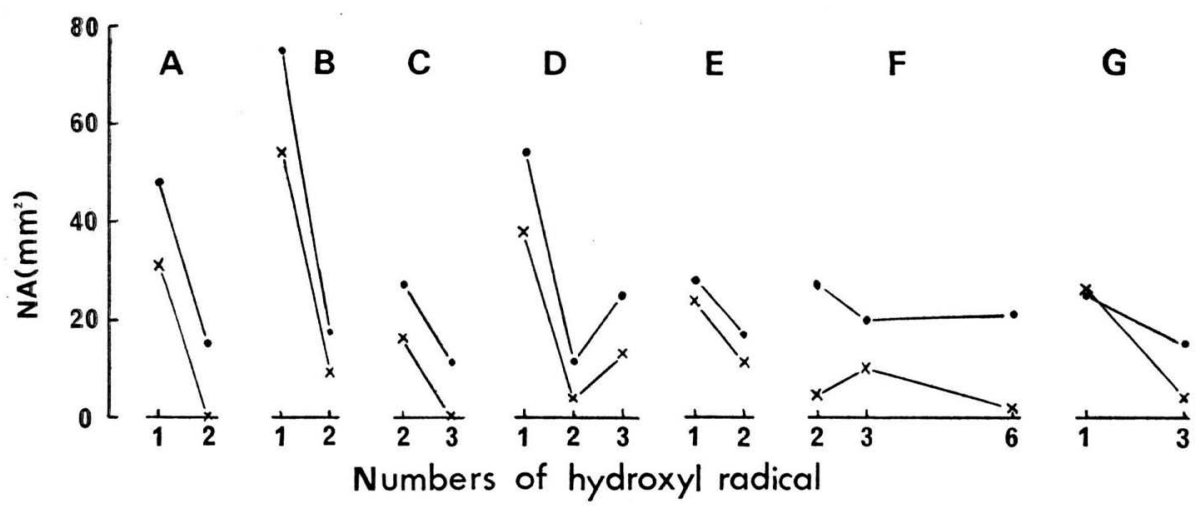

第 4 図 NA 飞打よぼす水酸基の数の影響
A. $\mathrm{C}_{2}$ alcohol の IPM 溶液.
B. $\mathrm{C}_{3}$ alcohol の IPM 溶液.
D. $\mathrm{C}_{4}$ alcohol $の$ IPM 溶液.
E. $\mathrm{C}_{5}$ alcohol $の$ IPM 溶液.
C. $\mathrm{C}_{4}$ alcohol の水溶液.
G. $\mathrm{C}_{6}$ alcohol の IPM 溶液.
$50 \%$ 溶液.
F. $\mathrm{C}_{6}$ alcohol の水溶液.
$\times-25 \%$ 溶液. 
1-2） 水酸基の数との関係

水酸基の数が異なる Alcohol 皮内注入による E 610 扎よび NA を同一炭素数のものごとに, 水酸基の数 との関係において第 $3 \mathrm{~A} \sim \mathrm{G}$ 打よび $4 \mathrm{~A} \sim \mathrm{G}$ 図示す.

第 3 D図に示した $\mathrm{C}_{4}$ diol と $\mathrm{C}_{4}$ triol の関保を除くと, $\mathrm{C}_{2} \sim \mathrm{C}_{6}$ の Alcohol による E610 はいずれる水 酸基の增加とは逆に減少した。 $\mathrm{C}_{4}$ diol と $\mathrm{C}_{4}$ triol による逆転した $\mathrm{E} 610$ も Butanol によるるのよりる明ら かに弱度であったので, $\mathrm{C}_{2} \sim \mathrm{C}_{6}$ の Alcohol による $\mathrm{E} 610$ は水酸基の数の増加に伴って減少するものである.

$\mathrm{NA}$ についても, 第 $4 \mathrm{D}$ と $4 \mathrm{~F}$ 図に示した $\mathrm{C}_{4}$ と $\mathrm{C}_{6}$ の Alcohol の一部成績を除くと, 水酸基の数の増加 によってNA の減少が認められた。

1-3）異性体間の比較

Propanediol-1.2 と - 1.3, Butanediol-2.3, -1.3 と - 1.4 㧊よび Hexanediol-1.6 と -2.5 とよるE 610 と NA 孝第1表に示す. 各異性体間において有意的に異なったのは 50\% Hexanedio1 による E610なら びに 25\% Hexanediol によるNA のみであって, ほとんどのこれら二価 Alcohol と拈ける罳性体間の作用は 有意的に相違するすのでなかった。

第 1 表 二価 Alcohol 汇牧将る異性体間の作用比較

\begin{tabular}{c}
\hline \multicolumn{1}{c|}{ 液 } \\
\hline 炭素数
\end{tabular}

* $\mathrm{p}=0.05$ 亿て有意差を示す.

1-4） Polyoxyethylene glycol の分子量との関係

諸種分子量の Polyoxyethylene glycol 皮内注入による E610 抢よび NA を第 2 表に示す. 50 特よび30\% Polyoxyethylene glycol による E610 は低分子量域に执いて分子量の増加に伴って著明に減少したが, 高分子 量域では分子量に関係なくほぼ一定であった。しかし，0.5M Polyoxyethylene glycol による E610は分子量 の大小にかかわらず, 拈おむ权一定であった。従って, 第 5 図に示すごとく, 分子量と E 610 との間係は\%濃 度では双曲線状であり, M濃度ではX軸汇平行な直線であった。

Polyoxyethylene glycol 皮内注入による NA の結果も第 2 表に示す. 高分子量の Polyoxyethylene glycol (No. 4000 と No. 6000) 皮内注入局所はその他 Alcohol 飞よって生じた NA とは外見上䔬なった Nonblued area を生じ, これら glycol が拡散せずに貯溜しているような状態に見党たので, これら NA を表から 除外した. 30\% Polyoxyethylene glycol はNAを作らなかったが, 50\% Polyoxyethylene glycol はいずれ の分子量のものもほぼ同等の NA を形成した.

一方, 0.5M 濃度の Polyoxyethylene glycol では分子量 400 以下のものは NA を生じなかったが, 分子 量 600 以上のそれらは NA を形成した. 
第 2 表 Polyoxyethylene glycol による E610 と NA

\begin{tabular}{|c|c|c|c|c|c|c|c|c|}
\hline \multirow{2}{*}{ 物 } & \multirow{2}{*}{ 名 } & \multirow{2}{*}{ 分子量 } & \multicolumn{3}{|c|}{ E 610} & \multicolumn{3}{|c|}{ NA } \\
\hline & & & $30 \%$ & $50 \%$ & $0.5 \mathrm{M}$ & $30 \%$ & $50 \%$ & $0.5 \mathrm{M}$ \\
\hline Polyoxyethylene glycol & No. 200 & 200 & 0.24 & 0.28 & 0.07 & 0 & 19 & 0 \\
\hline Polyoxyethylene glycol & No. 300 & 300 & 0.15 & 0.16 & 0.08 & 0 & 17 & 0 \\
\hline Polyoxyethylene glycol & No. 400 & 400 & 0.13 & 0.16 & 0.06 & 0 & 14 & 0 \\
\hline Polyoxyethylene glycol & No. 600 & 600 & 0.16 & 0.14 & 0.07 & 0 & 12 & 10 \\
\hline Polyoxyethylene glycol & No. 1000 & 1000 & 0.04 & 0.08 & 0.07 & 0 & 17 & 11 \\
\hline Polyoxyethylene glycol & No. 1540 & 1450 & 0.04 & 0.09 & 0.07 & 0 & 17 & 18 \\
\hline Polyoxyethylene glycol & No. 4000 & 1950 & 0.04 & 0.04 & & - & - & \\
\hline Polyoxyethylene glycol & No. 6000 & 8400 & 0.04 & 0.04 & & - & - & \\
\hline
\end{tabular}

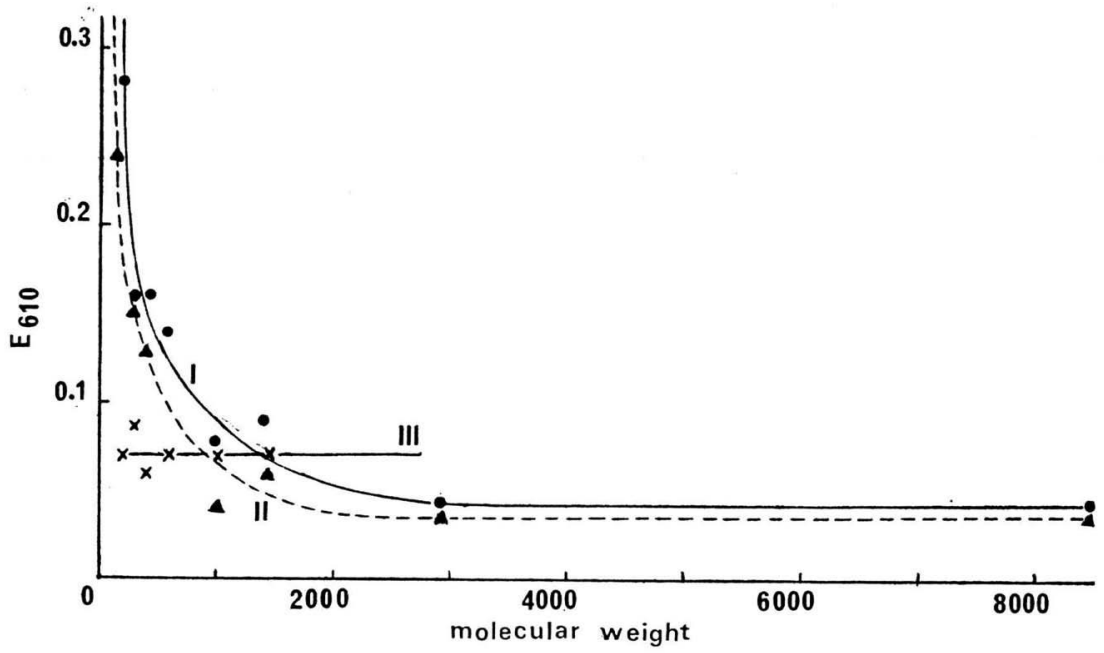

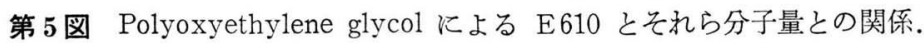

I. $50 \%$ 溶液. III. $25 \%$ 溶液. III. $0.5 \mathrm{M}$ 溶液.

\section{2) 抗 Histamine 薬の影響}

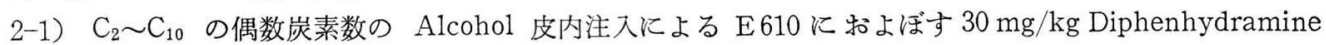
の影響を抑制率にて第3 表に示す。 Diphenhydramine A Alcohol 皮内注入の $1 ， 2$ 㐨よび $3^{\text {h }}$ 前に投与した が，Ethanol による E610 は Diphenhydramine 前処置のどの時間間隔ににおいても Diphenhydramine に よって部分的な抑制を受けた. Butanol とよる E 610 は $1^{\mathrm{h}}$ 前に投与した Diphenhydramine によって抑制さ れる傾向を示したが，2特よび $3^{\mathrm{h}}$ 前に投与したものでは抑制を受けなかった。 Hexanol, Octanol および Decanol は抑制されなかった。

2-2） 2-1 の成績から低級 Alcohol，(少なくとも Ethanol) による E610 は Histamine 遊離と関連ある ことが示唆される。一方, 遊離 Histamine および皮内注射した Histamine の作用は速效的かつ一過性である ので，低級 Alcohol による E610 そついて，それら time course そ拉よぽす Diphenhydramine の影響を 検討した。，その結果を第 4 表に示す。

0.01\% Histamine そよる E 610 は Diphenhydramine 前処置の有無にかかわらず, Histamine を Evans blue 投与 $1^{\mathrm{h}}$ 前に皮内注射した場合, ほとんど無視し得る反応であった. Histamine Evans blue 静注と同 時に皮内注射した場合 (時間間隔 $\mathrm{O}^{\mathrm{h}}$ ) には Diphenhydramine によって68\%阻害された。皮内注射と Evans 
第3 表 50\% Alcohol 皮内注入による E610 に特 よぼす $30 \mathrm{mg} / \mathrm{kg}$ Diphenhydramine の影響（抑制 率にて示す)

\begin{tabular}{l|ccc}
\hline \multirow{2}{*}{ 質 名 } & \multicolumn{3}{|c}{ Diphenhydramine 前処置の時間 } \\
& $\overbrace{1^{\mathrm{h}}}$ & $2^{\mathrm{h}}$ & $3^{\mathrm{h}}$ \\
\hline Ethanol & $15.5 \%$ & $28.5 \%$ & $20.7 \%$ \\
Butanol & 25.5 & 10.9 & -39.3 \\
Hexanol & 9.3 & -34.8 & 28.5 \\
Octanol & -25.8 & -3.6 & 11.2 \\
Decanol & -36.2 & 4.9 & -19.4
\end{tabular}

第 4 表 $25 \%$ 低級 Alcohol 皮内注入による E610の time course に拉よ゙す $30 \mathrm{mg} / \mathrm{kg}$ Diphenhydramine の影響（抑制率にて示す）

\begin{tabular}{|c|c|c|c|c|}
\hline \multirow{2}{*}{ 物 } & \multirow{2}{*}{ 質 } & \multirow{2}{*}{ 名 } & \multicolumn{2}{|c|}{$\begin{array}{c}\text { 皮内注射 } \rightarrow \text { Evans blue 静 } \\
\text { 注の時間間隔 }\end{array}$} \\
\hline & & & $0^{\text {h }}$ & $1^{\mathrm{h}}$ \\
\hline \multicolumn{3}{|c|}{ Ethanol } & $23 \%$ & $-1 \%$ \\
\hline \multicolumn{3}{|c|}{ Propanol } & 31 & 11 \\
\hline \multicolumn{3}{|c|}{ Butanol } & 24 & 4 \\
\hline \multicolumn{3}{|c|}{$0.01 \%$ Histamine } & 68 & - \\
\hline
\end{tabular}

blue 静注の時間間隔 $0^{\mathrm{h}}$ に和ける Ethanol, Propanol 和よび Butanol による E610 はそれぞれ Diphenhydramine によって23，31および24\%抑制された。しかしその時間間隔 $1^{\mathrm{h}}$ のものについてはDiphenhydramine による有意的な抑制は認められなかった。

\section{3）二・三抗炎症薬の影響}

第 5 表に示すごとく，皮内注射 $2^{\mathbf{h}}$ 前に投与した Sodium salicylate $(500 \mathrm{mg} / \mathrm{kg}$ ), Cortisone acetate (10 $\mathrm{mg} / \mathrm{kg})$ 版び Dipotassium glycyrrhitinate $(500 \mathrm{mg} / \mathrm{kg})$ そよって, 25および50\%の Ethanol, Butanol, Hexanol, Octanol および Decanol はいずれも有意的に抑制されなかった.

第 5 表 Alcohol 皮内注入による E610 におよぽす二・三抗炎症薬の影響

\begin{tabular}{|c|c|c|c|c|}
\hline Alcohols & 抗炎症薬 & $\begin{array}{l}500 \mathrm{mg} / \mathrm{kg} \\
\mathrm{Na} \text { Salicylate } \\
\text { (ip) }\end{array}$ & $\begin{array}{l}10 \mathrm{mg} / \mathrm{kg} \\
\text { Cortisone } \\
\quad \text { (im) }\end{array}$ & $\begin{array}{c}500 \mathrm{mg} / \mathrm{kg} \\
\mathrm{K}_{2} \text { Glycyrrhitinate } \\
\text { (ip) }\end{array}$ \\
\hline \multirow{2}{*}{ Ethanol } & $25 \%$ & $\rightarrow$ & $\rightarrow$ & $\rightarrow$ \\
\hline & $50 \%$ & $\rightarrow$ & $\downarrow$ & $\rightarrow$ \\
\hline \multirow{2}{*}{ Butanol } & $\{25 \%$ & $\downarrow$ & $\rightarrow$ & $\downarrow$ \\
\hline & $\{50 \%$ & $\downarrow$ & $\uparrow$ & $\downarrow$ \\
\hline \multirow{2}{*}{ Hexanol } & $\{25 \%$ & $\rightarrow$ & $\downarrow$ & $\downarrow$ \\
\hline & $\{50 \%$ & $\rightarrow$ & $\rightarrow$ & $\uparrow$ \\
\hline \multirow{2}{*}{ Octanol } & $25 \%$ & $\rightarrow$ & $\uparrow$ & $\uparrow$ \\
\hline & $50 \%$ & $\rightarrow$ & $\uparrow \uparrow$ & $\downarrow$ \\
\hline \multirow{2}{*}{ Decanol } & $25 \%$ & $\rightarrow$ & $\rightarrow$ & $\rightarrow$ \\
\hline & $50 \%$ & $\downarrow$ & $\rightarrow$ & $\downarrow$ \\
\hline
\end{tabular}

$\mathrm{t}$ 検定の結果 $\mathrm{p}=0.01$ で差を認めたものは矢印 2 本, $\mathrm{p}=0.1$ のものは矢印 1 本, 横向きの矢印は $\mathrm{p}=0.1$ でも差を示さなかったものである.下向きは抑制, 上向きは增強を示す。

\section{4) Alcohol 類の油/水分配率}

25\% Alcohol を含むIPM に水を加えて，それら混液を振盪した際， C 10 以上の Alcohol を含む系では静 置直後に透明な二層に分離したが， $C_{9}$ 以下の Alcohol 添加系では乳濁し，徐々に中間の乳濁層を挾んで透明な 上下層が生じた. Nonanol 添加系に拈ける乳濁層の消失速度は $\mathrm{C}_{8}$ 以下の Alcohol の系よりも速かった。乳濁 層の消失時間を正確に把握できなかったが，高級 Alcohol よりも低級 Alcohol にて乳化力大の傾向が見られ た。一晚放置しても完全に二層に分離しないものもあったが，乳濁層を除いた透明な上層 (IPM) と下層（水） を分取し，Gas chromatography の実験に供した。本実験条件は実際には IPM 75g, Alcohol $25 \mathrm{~g}$ および水 $75 \mathrm{~g}$ を用い, 室温にて行なった.

第6 表に示すごとく, IPM 層に分配した Alcohol 量（Pi）は炭素数の増加とともに増した，一方，水層の 
第 6 表 Alcohol の油/水分配率 (実験条件 : 室温, Alcohol 初濃度 $25 \mathrm{~g}$ )

\begin{tabular}{l|ccccc}
\hline \multirow{2}{*}{ Alcohols } & \multicolumn{3}{|c}{ Alcohol の収量 } & $\begin{array}{c}\text { 油/水分配率 } \\
\text { (Pi/Pw) }\end{array}$ & $100 \times \frac{\mathrm{Pi}}{\mathrm{Pt}}$ \\
\hline Methanol & IPM層(Pi) & 水層(Pw) & 全量 $(\mathrm{Pt})$ & & $1.3 \%$ \\
Ethanol & $0.27 \mathrm{~g}$ & $20.07 \mathrm{~g}$ & $20.36 \mathrm{~g}$ & 0.012 & 10.5 \\
Propanol & 2.14 & 18.15 & 20.29 & 0.118 & 54.48 \\
Butanol & 13.62 & $(11.38) *$ & $(25.00)$ & 1.197 & 88.8 \\
Pentanol & 26.70 & 3.38 & 30.08 & 7.899 & 99.8 \\
Hexanol & 29.25 & 0.05 & 29.30 & 585.000 & 100.0 \\
Heptanol & 27.43 & 0 & 27.43 & $\infty$ & 100.0 \\
Octanol & 27.52 & 0 & 27.52 & $\infty$ & 100.0
\end{tabular}

* Propanol の $\mathrm{Pw}$ は実測不能. 従って $\mathrm{Pw}=$ 初濃度 $25 \mathrm{~g}$ - $\mathrm{Pi}$ より求めた。

Alcohol 量 $(\mathrm{Pw})$ は $\mathrm{Pi}$ とは逆に炭素数の增加に伴って減少し， $\mathrm{C}_{6}$ より高級 Alcohol では水層中の 分布を認 めなかった. Propanol の Gas chromatogram 上の peak は水のものと重なるので, Pw を実測できなかっ た。従って,この $\mathrm{Pw}$ は初濃度 $25 \mathrm{~g}$ と $\mathrm{P}$ の差で求めた。 Pi と $\mathrm{Pw}$ の和である収量 $(\mathrm{Pt})$ は初濃度 $25 \mathrm{~g}$ より も低級 Alcohol の場合は少なく, 高級 Alcohol では多かった。 以上の実測值から求めた油/水分配率 ( $\mathrm{Pi} / \mathrm{Pw})$ と IPM 層に分配する Alcohol 量の百分此 $(100 \times \mathrm{Pi} / \mathrm{Pt})$ は当然のことながら炭素数の增加に従って增加し， $\mathrm{C}_{6}$ より高級 Alcohol ではそれぞれ $\infty$ 特よび $100 \%$ であった。

総括

Alcohol 類香皮内注射による局所作用は Histamine のごとく低用量で反応するものとは本質的に異なり， 高用量にて反応を示し，それら作用機転には炭素数と水酸基の比率に関係ある物理化学的性質特よび渗透圧が関 連するであろうと示唆し1), さらに, 化学構造的に炭素数, 二重結合, Aryl 基, 環状構造, Ether 結合および 異性体などによって何らかの影響を受け，その結果 Alcohol 類による血管透過性光進は親油反応であり， Non-blued area 形成は親水反応であろうと示唆して来た ${ }^{2)}$.

その後, 非 Ion 界面活性剂仡よる血管透過性充進（E610）の研究に扬いて, HLB-E610曲線が中等度 HLB に最高活性を示すこと7，ならびにそれら作用機序が毛細血管壁ないしはその内皮細胞膜脂質機能の界面活性沉 よる擾乱に基因するらしいこと委を示した． 特に，HLB-E610 曲線が第6 図に示す $n$-Alcohol の炭素数 - E 610 相関図に類似していたので, Alcohol 之非 Ion 界面活性剤の E610 活性機序の関連に括いて, 更なる検討 を施し, 先報の成績2) と併せて, 高用量の Alcohol 類皮内注入による E610 および NA 生成機転に浩察を加 学る.

n-Alcohol 飞批る炭素数 - E610 曲線は炭素数 6 ～8 亿最高活性を示し (第 6 図), 最高活性を示す A1cohol およびそれよりる低級なものに扎いては水酸基と Ether 結合の附加が E 610 活性を漰弱せしめ, また， 高級 Alcohol では Aryl 基, 二重結合拈よび環状構造を有するAlcohol はそれらに対応する炭素数の n-Alcohol よりも強い活性を示す。このことは非 Ion 界面活性剤において最高活性を示するのおよびそれよりる高 HLBの るのに親水基 (Oxyethylene 基) を附加すると E610 活性が低下し, 低 HLB のものでは親水基の添加が活性 を增強するという結果と一致する。一価拈よび二価 Alcohol の異性体間では E 610 活性に若干の相違はあるが 著明でない，これは異性体閒においては極性あるいは親水性に著明な差がないことに基づくであろう．かように 化学構造から見た Alcohol と非 Ion 界面活性剤の E610 出現様式はきわめて類似性を示す.

さらに, $n$-Alcohol を含む油 (IPM)-水系を混和すると炭素数10以上のものにおいては直らに二層に分離し Nonanol では不安定ではあるが, 乳濁層を形成する，より低級なものはNonanol よりも安定な乳濁層を作る. 従って, Octanol 以上の高級 Alcohol では炭素数の增加とともに乳化力（界面活性機能）が低下することを示 


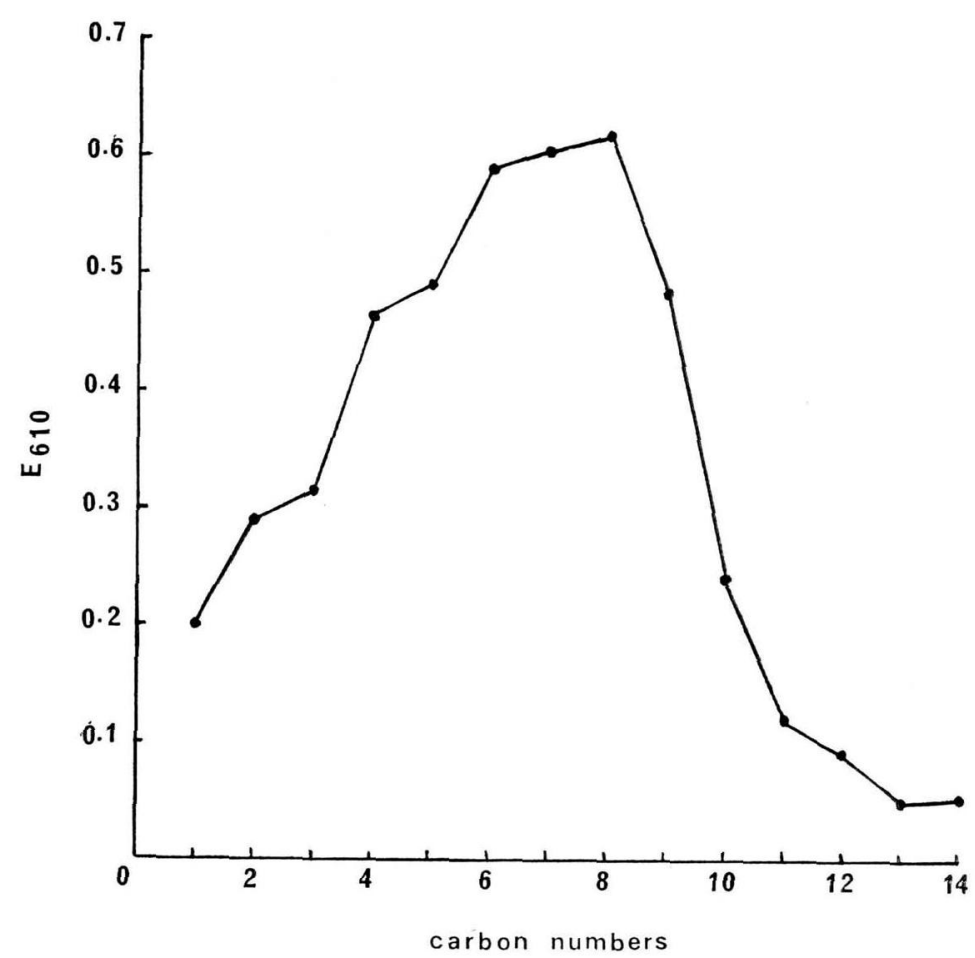

第 6 図 n-Alcohol に打ける E610 と炭酸数の相関図 ${ }^{23}$

す. 一方, これら Alcohol の油 (IPM)-水分配については炭素数が増加するに従って, 油層への分配が增し, Hexanol 以上の高級 Alcohol は水層に検出されない。これら物理化学的力価と炭素数化関する二つの相関図を 組合わせると, 第6 図の E 610- 炭素数曲線によく一致する. 従って, 低級 Alcohol の E610 活性は油-水分配 性に, 高級 Alcohol のそれは乳化力（界面活性機能）によって規制を受けるのであうら，とれ故に, Alcohol 類による E610 活性機序は非 Ion 界面活性剂同様, 界面活性火上る生体内脂質に対する影響に基づくものと推 論さ礼る。

近藤9》は赤血球周囲の媒質の表面張力がある限界点に達すると溶血を生ずるという Pethica ら ${ }^{109}$ の成績を 基に, Butanol p Pentanol の溶血作用は非 Ion 界面活性剤のそれと本質的には同じであろらと指摘している. このことは溶血と血管透過性光進との違いはあっても，先きの推論を支持するものであろう．

皮内注入中心部にしばしば認める Non-blued area (NA) が壞死様”西るいは硬結様(1)であることはすで に報告したごとくである.Alcohol類の NA 形成活性が蛋白変性に由来するかも知れないことが示唆されて拉 $り^{22}$ ，また，電解質皮内注射によるNA の生成はそれら蛋白変性能に比例することが確認されている NA 活性 (Alcohol 類のものも含めて) 蛋白変性作用と関連することはかなり確かである. Alcohol によるNA とそれら化学構造との関係に関する本報告の成績においてる，特に水酸基の数の增加が NA 活性を低下させる

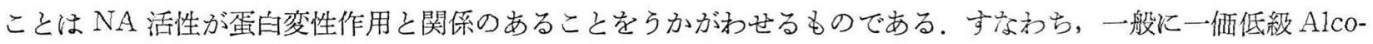
hol の蛋白変性能は知られているところであるが，多価Alcohol による蛋白変性についての言及は少ないこと による.

Polyoxyethylene glycol 類による E610 と分子量との関係は％濃度による比較では双曲線状を呈し，M濃 度では分子量に関係なく一定の力価を示す。それに対し, NA 活性は\%濃度の場合分子量とは無関倸に一定であ り, M濃度では分子量の增大とともに強度となる。従って, これら Glycol 類に和ける E610 活性は分子単位 の, NA 活性は Monomer (Oxyethylene) 単位の反応に基つくものとも考光得る. \%濃度に特ける分子量と $\mathrm{E}$ 
610 との双曲線的関係は渗透圧が分子量と逆数関係を示すので, 渗透压要因性のものと想定される．また, 一定 M濃度にお㹁る分子量増加化う NA 活性の元進は分子量增加が Oxyethylene 単位の濃度增加を生ずるので, 生体内蛋白に詨する脱水和能の立進によるものであろう.

代表的な Alcohol であるEthanol が組織 Histamine を遊離することはよく知られているところであり ${ }^{13)}$, Ethanol 皮内注入による血管透過性立進が Diphenhydramine によって減弱することも示されている゙ . 一連の

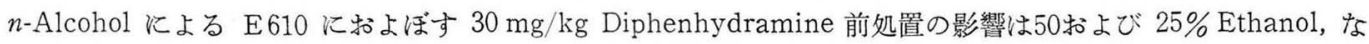
らびに25\%の Propanol と Butanol の E610 活性に抑制として認められるが, 50\%の Butanol, Hexanol, Octanol 物よび Decanol のものには認められない, 従って, 低級 Alcohol による E610はそれ机らの Histamine 遊離性に由来する作用機序を一部含むであろうが，高級 Alcohol によるものはそれを含まないであろう。しか し，Diphenhydramine によって 25\% Butanol によるE610は抑制を受け，50\% Butanol によるものは抑制 を受けないととは高級 Alcohol による E610 活性が Histamine 遊離に依存しないといらよりも，とれら反応 に占める Histamine 遊離の役割が無視し得る程度のものであることを示すであるう.

低級 Alcohol 皮内注入後 1 2 $2^{\mathrm{h}}$ 間に生ずる E 610 は Diphenhydramine によって抑制されないので, こ れら Alcohol による Histamine 遊離は皮内注入後 $1^{\mathrm{h}}$ 以内に生ずることが示唆される.

n-Alcohol 皮内注入による E 610 は Salicylate, Glycyrrhitinate 特よび Cortisone によって抑制され難 い. しかし，Ethanol による血管透過性六進が Salicylate 汇よって抑制される傾向にある( ともいわれている. このような問題をも含めて, Histamine 以外の Chemical mediator 関与の作用機序に関する今後の問題もある が，一連の Alcohol 類皮内注入による作用機序としては，1）Alcohol 類の界面活性力価による生体内脂質機能 の擾乱に基因する血管透過性圥進，2）特に低級 Alcohol に特ける Histamine 遊離に基づく血管透過性圥進, ならびに 3）低級 Alcohol の蛋白変性作用に由来するであろう NA の生成などの可能性がある. 一方, Polyoxyethylene glycol による E610 には渗透圧に基因する作用機序が含まれること，およびそれら Glycol によ る NA 恃蛋白変性作用（恐らく蛋白に対する脱水和能）によって生成されるかも知れないことが示唆される.

$$
\text { なお, 本論交要旨は第32回日本薬理学会近畿部会において口演した。 }
$$

\section{文献}

1) 鈴木 守: 日薬理誌, 57, 501 (1961).

2) 鈴木 守, 新茾弘祐 : 同誌, 62, 241 (1966).

3) Suzuki, M., Arai, H. : Jap. J. Pharmac., 16, 25 (1966).

4) 鈴木 守, 本好捷宏 : 日薬理誌, 61, 263 (1965).

5) Sfector, G. B.: Progress in the Biological Sciences in relation to Dermatology, p. 295, Cambridge Univ. Press (1960).

6) 鈴木 守, 本好捷宏: 日薬理誌, 61, 369 (1965).

7) Suzuki, M., Motoyoshi, K., Horikawa, H., Arai, H.: Scientific Papers in 5th Cogress of International Federation of Societies of Cosmetic Chemists, p. 1 (1968); 鈴木 守: 表面, 6, 392 (1968).

8) Suzuki, M., Motoyoshi, K., Horikawa, H., Arai, H. Jap. J. Pharmac., 17, 525 (1967).

9) 近藤 保: 表面, 5, 630 (1967).

10) Pethica, B. A., Schulman, J. H. : Biochem. J., 53, 177 (1953).

11）鈴木 守：日薬理謢，60, 62 (1964).

12）堀川寿夫, 鈴木正巳, 鈴木 守：同誌, 64, $185 \S$ (1968).

13）山崎英正 : 日新医学, 47,717 (1960). 